\title{
PREDIKSI INFLOW DAN OUTFLOW UANG KARTAL DI PROVINSI BALI DENGAN METODE NEURO-FUZZY
}

\author{
I Kadek Mentik Yusmantara ${ }^{1 \S}$, G. K. Gandhiadi², Luh Putu Ida Harini ${ }^{3}$
}

\begin{abstract}
${ }^{1}$ ProgramStudi Matematika,Fakultas MIPA - Universitas Udayana [Email: mentikyu smantara@ gmail.com] ${ }^{2}$ ProgramStudiMatematika, Fakultas MIPA - Universitas Udayana [Email: gandhiadi@ unud.ac.id]

${ }^{3}$ ProgramStudi Matematika, Fakultas MIPA - Universitas Udayana [Email: ballidah @ unud.ac.id]

${ }^{\S}$ Corresponding Author
\end{abstract}

\begin{abstract}
In this paper, we present a novel approach to data-driven neuro-fuzzy modeling, which aims to create accurate monthly inflow and outflow forecast of money (MO) in Bali Province. The data is monthly time series included some religious ceremony identification variables and a monthly dummy variable from January 2011 to March 2019. Well known, Bali Province has unique cultures, the only one province which Hinduism majority religion in Indonesia, and listed as top tourism destination in the world. The neuro-fuzzy models were created using ANFIS architecture and sliding window time series analysis, then simulated using walk forward validation, interpreted using MAPE, and NRMSE. Based on the simulation of the last 24 months, the model of inflow obtained MAPE 23.33\% (worth considering) and NRMSE 18.68\% (accurate). Meanwhile, the model of outflow obtained MAPE $19.24 \%$ (accurate) and NRMSE $8.71 \%$ (very accurate). These models and their pieces of information could assist the central bank in Bali Province to prepare cash for money (M0) outflow and managed technic for counting money (MO) inflow.
\end{abstract}

Keywords: forecast, inflow and outflow, money, neuro-fuzzy, religious

\section{PENDAHULUAN}

Inflow dan outflow uang kartal (M0) merupakan dua indikator peredaran uang (M1) di tingkat wilayah. Transaksi penyimpanan uang kartal masyarakat dan perbankan ke bank sentral disebut inflow uang kartal, sedangkan transaksi penarikan uang kartal masyarakat dan perbankan dari bank sentral disebut outflow uang kartal. Sebagai indikator peredaran uang di tingkat wilayah, inflow dan outflow turut memengaruhi keberlangsungan sistem pembayaran pada sektor rumah tangga, kestabilan perekonomian, proses penciptaan uang, beserta clean money policy. Prediksi peredaran uang yang menjadi agenda bulanan bank sentral dan peserta operasi moneter untuk mendukung kegiatan transaksi operasi pasar terbuka merupakan salah satu upaya untuk menjaga kestabilan uang beredar (Bank Indonesia, 2013).

Berdasarkan data penduduk menurut agama tahun 2019 yang diperoleh langsung dari kantor Perwakilan Wilayah Kementerian Agama Provinsi Bali terdapat $85,29 \%$ penduduk
Hindu; $12,08 \%$ penduduk Islam; $0,7 \%$ penduduk Budha; $1,07 \%$ penduduk Kristen; $0,86 \%$ penduduk Katolik; dan $0.02 \%$ penduduk Konghucu dari 4.592.853 penduduk Provinsi Bali. Sehingga dapat diketahui perayaan hari raya agama Hindu dirayakan oleh sebagai besar penduduk provinsi Bali. Selain itu aktivitas masyarakat Provinsi Bali dapat dipengaruhi oleh hari raya Idul Fitri karena termasuk dalam hari libur nasional dan merupakan hari raya yang dirayakan oleh hampir sebagian besar masyarakat selain Hindu. Perbedaan karakteristik keagamaan di Provinsi Bali dibandingkan Provinsi lainnya di Indonesia memerlukan suatu model khusus yang dapat memprediksi aliran inflow dan outflow uang kartal. Berdasarkan pertimbangan pengaruh hari raya dan pola bulanan dapat dilakukan suatu studi untuk membuat model prediksi inflow dan outflow uang kartal di Provinsi Bali.

Neuro-fuzzy merupakan salah satu metode yang dapat digunakan untuk membentuk model inflow dan outflow uang kartal sebagai gabungan dari metode neural network dan 
logika fuzzy. Neural network merupakan salah satu metode yang dapat digunakan untuk memprediksi kasus-kasus deret waktu. Neural network yang menggunakan arsitektur standar multilayer perceptron untuk pemodelan berbasis data dengan banyak variabel sering menyajikan konvergensi error yang tidak stabil, sehingga pemilihan jumlah iterasi pembelajaran (epoch) pada arsitektur multilayer perceptron sangat menentukan keakuratan proses pembelajaran. Salah satu sistem neurofuzzy yang dapat dijadikan alternatif yaitu adaptive neural fuzzy inference system (ANFIS) adalah sistem yang menggunakan multi-layer feedforward network dengan metode pembelajaran teraw asi untuk membuat model berdasarkan sistem fuzzy TagakiSugeno. ANFIS dapat memberikan konvergensi error yang lebih stabil untuk kompleksitas jaringan yang sama, sehingga keakuratan proses pembelajaran dapat terjaga dengan lebih baik karena perbedaan konvergensi absolut lebih stabil dan mengecil mendekati konvergensi error-nya (Navarro, et al., 2013).

Studi ini bertujuan untuk membentuk pendekatan baru menggunakan identifikasi hari raya dan pola bulanan dalam pemodelan neurofuzzy berbasis data, yang bertujuan untuk membuat prediksi inflow dan outflow uang kartal bulanan yang akurat di Provinsi Bali. Hasil studi ini diharapkan dapat membantu perbankan khususnya bank sentral memanajemen aliran uang kartal dan sebagai referensi terkait menjaga kestabilan uang beredar.

\section{METODE PENELITIAN}

Data yang digunakan dalam studi ini adalah deret waktu dua variabel yaitu inflow dan outflow uang kartal sebanyak 99 data dengan interval bulanan dari Januari 2011 sampai dengan Maret 2019 dari Divisi Sistem Pembayaran dan Pengelolaan Uang Rupiah Bank Indonesia Provinsi Bali. Gambar 1 berikut merupakan diagram alir analisis data sebagai garis besar metode dalam studi ini.

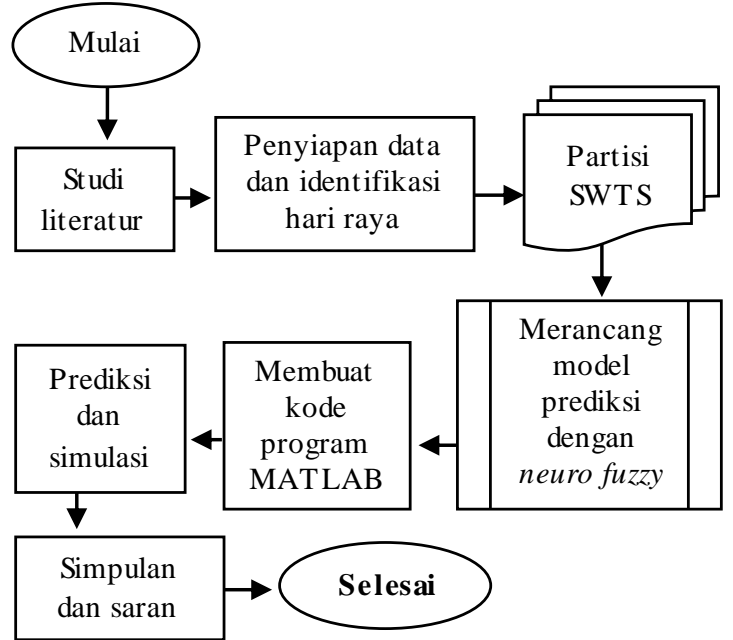

Gambar 1. Diagram Alir Analis is Data

\subsection{Penyiapan Data}

Identifikasi variabel hari raya dan dummy bulan dilakukan menggunakan program BalaBali Kalender (BalaBali, 2012).

Tabel 1. Identifikasi Variabel Hari Raya dan Dummy Bulan

\begin{tabular}{|l|l|l|l|}
\hline \multicolumn{2}{|l|}{ Variabel } & Identifikasi & Perhitungan \\
\hline $\boldsymbol{a}$ & Inflow & Data BI & Data BI \\
\hline $\boldsymbol{b}$ & Outflow & Data BI & Data BI \\
\hline $\boldsymbol{g}$ & $\begin{array}{l}\text { Galungan } \\
\text { dan } \\
\text { Kuningan }\end{array}$ & $\begin{array}{l}\text { 28 hari } \\
\text { (Sudah } \\
\text { termasuk } \\
\text { rentetannya) }\end{array}$ & $\begin{array}{l}\text { Hitung } \\
\text { mundur 28 } \\
\text { hari dari } \\
\text { Kuningan }\end{array}$ \\
\hline $\boldsymbol{f}$ & Idul Fitri & $\begin{array}{l}\text { 28 hari } \\
\text { (dua hari } \\
\text { puncak yaitu } \\
\text { H1 dan H2) }\end{array}$ & $\begin{array}{l}\text { Mundur tiga } \\
\text { minggu dari } \\
\text { H1 dan maju } \\
\text { satu minggu } \\
\text { dari H2 }\end{array}$ \\
\hline $\boldsymbol{n}$ & Nyepi & $\begin{array}{l}\text { 14 hari } \\
\text { (sudah } \\
\text { termasuk } \\
\text { rentetannya) }\end{array}$ & $\begin{array}{l}\text { Hitung } \\
\text { mundur 14 } \\
\text { hari dari raya } \\
\text { Ngembak } \\
\text { Geni }\end{array}$ \\
\hline $\boldsymbol{s}$ & $\begin{array}{l}\text { Saras wati } \\
\text { dan } \\
\text { Pagerwesi }\end{array}$ & $\begin{array}{l}\text { 7hari (sudah } \\
\text { termasuk } \\
\text { keduanya) }\end{array}$ & $\begin{array}{l}\text { Hitung } \\
\text { mundur 7 hari } \\
\text { dari raya } \\
\text { Pagerwesi }\end{array}$ \\
\hline $\boldsymbol{m}$ & Bulan & Nama bulan & 1-12 \\
\hline
\end{tabular}

Data bulan ke $-i$ dari 1-99 dapat dirumuskan ke dalam bentuk vektor baris sebagai variabel $x_{i}$.

$x_{i}=\left[\begin{array}{lllllll}a_{i} & b_{i} & g_{i} & f_{i} & n_{i} & s_{i} & m_{i}\end{array}\right]$ 
Data tersebut selanjutnya diproses menggunakan kode program MATLAB 2016a pada subbab berikut.

\subsection{Simulasi Walk Forward Validation}

Pembagian data test dan train untuk tiap prediksi dalam simulasi inflow dan outflow uang kartal di Provinsi Bali menggunakan metode walk forward validation. Metode ini mengizinkan penggunaan data aktual yang dibandingkan untuk test sebelumnya dalam data train untuk melakukan test berikutnya secara urut berdasarkan deret waktu yang ditentukan. Simulasi yang diujikan pada setiap model yang dirancang yaitu 24 bulan terakhir.

\subsection{Normalisasi Data}

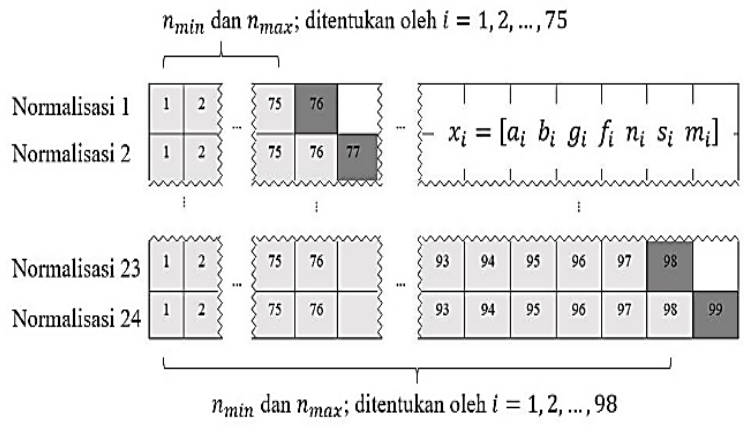

Gambar 2. Normalisasi dalam Simulasi Walk

\section{Forward Validation}

Gambar 2 menunjukkan normalisasi data dalam simulasi walk forward validation selama 24 bulan terakhir. Proses normalisasi hanya diterapkan pada data inflow $\left(a_{i}\right)$ dan outflow $\left(b_{i}\right)$. Data inflow dan outflow baik test maupun train dinormalkan berdasarkan masing-masing nilai minimal dan maksimal kolom inflow dan outflow dalam data train. Normalisasi dilakukan untuk membentuk data simulasi yang lebih menghindari hasil prediksi negatif atau terlampau besar.

\subsection{Sliding Window Time Series Analysis}

Konsep sliding window time series analysis (SWTS) digunakan untuk mempersiapkan data berdasarkan catatan waktu dan prediksi yang telah ditentukan, kemudian diproses untuk menghasilkan suatu prediksi baru (Mozaffari, et $a l .$, 2014). Didefinisikan nilai panjang segmen sebagai variabel $l$ yang menunjukkan seberapa banyak deret waktu sebelumnya sebagai banyak input partisi yang dipasangkan dengan partisi output sebagai deret waktu berikutnya.

$P=[I O]$

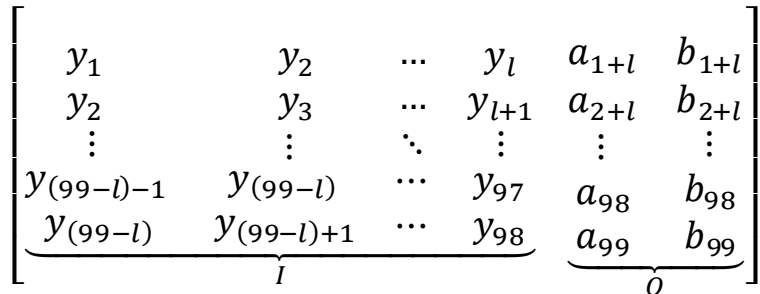

$y_{i}=\left[a_{i} b_{i}\right]$

diperoleh matriks $P$ yang terdiri dari matriks $I$ sebagai partisi input, $O$ sebagai partisi output. Matriks $P$ yang memuat hari raya dan bulan didefinisikan sebagai berikut.

$P=[\underbrace{I H M}_{\text {input }} \underbrace{O}_{\text {output }}]$

dengan $H$ menyatakan nilai variabel hari raya di bulan yang diprediksi, dan $M$ menyatakan dummy bulan di bulan yang diprediksi. Dapat didefinisikan state space matriks dari suatu proses prediksi deret waktu dengan suatu intelligent predictor $\psi$ (Mozaffari, et al., 2014). State space berikut merupakan matriks data yang akan disesuaikan berdasarkan model yang dibuat.

$$
\begin{aligned}
& \text { output }=\psi(\text { input })
\end{aligned}
$$

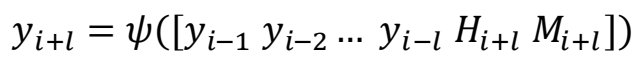

$$
\begin{aligned}
& {\left[\begin{array}{ll}
a_{i+l} & b_{i+l}
\end{array}\right]=} \\
& \psi\left(\left[\begin{array}{llllllllll}
y_{i-1} & y_{i-2} & \ldots & y_{i-l} & g_{i+l} & f_{i+l} & n_{i+l} & s_{i+l} & m_{i+l}
\end{array}\right]\right)
\end{aligned}
$$

\subsection{Arsitektur ANFIS}

Arsitektur ANFIS untuk memprediksi inflow dan outflow uang kartal di Provinsi Bali terdiri dari lima layer menggunakan rule base Sugeno yang dijalankan dengan algoritme pembelajaran hybrid. Tiap variabel input difuzzikan dengan 2 variabel linguistik, yaitu RENDAH dan TINGGI. Arsitektur ini dihasilkan menggunakan MATLAB 2016a yaitu Fuzzy Logic Toolbox dan proses pembelajaran hybrid dijalankan menggunakan syntax "genfis 1" untuk menghasilkan arsitektur ANFIS grid partition. Konfigurasi proses pembelajaran menggunakan nilai epoch 30 . 


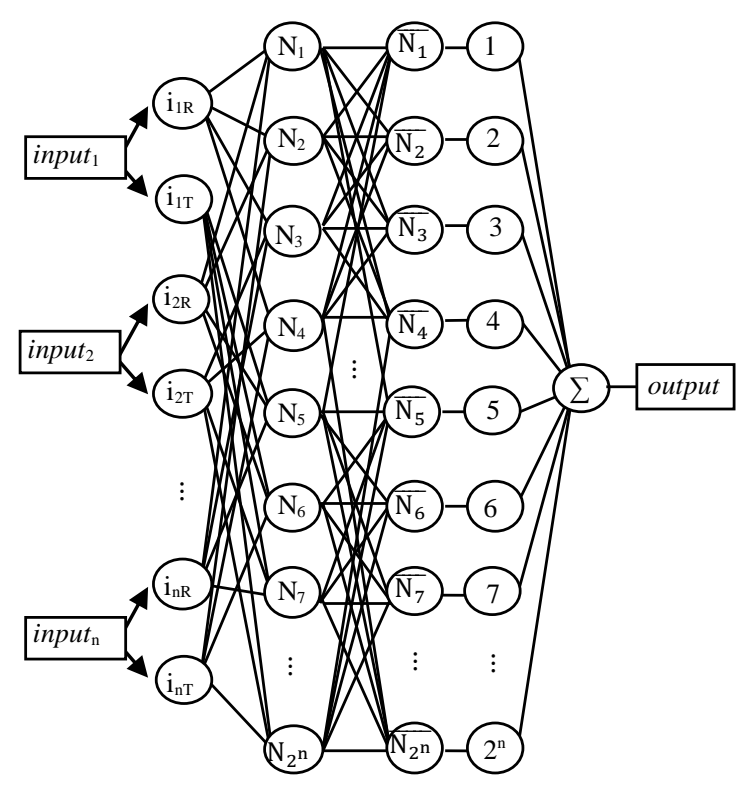

Gambar 3. Arsitektur ANFIS grid partition

\section{i. Layer 1: Fuzzifikasi}

Fuzzifikasi tiap input sebagai premis aturan fuzzy dengan dua fungsi keanggotaan generalized bell.

$$
\mu(x)=\frac{1}{1+\left|\frac{x-c}{a}\right|^{2 b}} ; b=1
$$

\section{ii. Layer 2: Aturan fuzzy (hidden layer)}

Tiap input pada penelitian ini difuzzikan ke dalam dua variabel linguistik, sehingga aturan fuzzy yang dibentuk arsitektur grid partition menggunakan MATLAB adalah sebanyak $2^{n}$. Dalam hal ini layer dua berisi neuron sebanyak $2^{n}$, dengan $n$ menyatakan jumlah kolom input yang dihubungkan dengan operator AND untuk membentuk aturan fuzzy.

\section{iii. Layer 3: Normalised Fire Strength}

Tiap neuron pada layer tiga menghitung normalised fire strength tiap $\alpha$-predikat pada layer dua yang terhubung dengannya.

$\bar{w}_{i}=\frac{w_{i}}{\sum_{i=1}^{n} w_{i}} ; i=1,2, \ldots, 2^{n}$

\section{iv. Layer 4: Defuzzifikasi}

Layer empat merupakan proses defuzzifikasi dengan menggunakan consequent parameter yang bersesuaian dengan aturan fuzzy sugeno pada layer dua.

$$
\begin{aligned}
& \vartheta_{i}=\bar{w}_{i} f_{i}=; i=1,2, \ldots, 2^{n} \\
& f_{i}=c_{1}{ }_{i} \text { input } 1_{i}+c_{2}{ }_{i} \text { input } 2_{i}+\cdots+ \\
& c_{n_{i}} \text { inputn }+c_{n+1_{i}}
\end{aligned}
$$

\section{v. Layer 5: Output keseluruhan}

Tiap sinyal yang menuju tiap neuron pada layer lima akan dihitung output-nya berupa jumlahannya pada masing-masing neuron.

$\vartheta_{1,2}=\sum_{i}^{n} \bar{w}_{i} f_{i} ; n=1,2,3, \ldots 2^{n}$

\subsection{Denormalisasi}

Proses denormalisasi mengembalikan nilai output prediksi dan output aktual yang dinormalkan ke bentuk sebelumnya. Denormalisasi dilakukan pada setiap prediksi dalam satu kesatuan simulasi walk forward validation berdasarkan parameter nilai minimal dan maksimal tiap kolom data train.

\subsection{Simulasi dan Evaluasi Performa Prediksi}

Evaluasi simulasi dilakukan berdasarkan perhitungan MAPE dan NRMSE. Interpretasi akurasi model yaitu kurang dari $10 \%$ sangat akurat, dari 10\% hingga $20 \%$ akurat, lebih dari $20 \%$ hingga $50 \%$ wajar, dan lebih dari $50 \%$ tidak akurat (Lewis, 1982).

\section{HASIL DAN PEMBAHASAN}

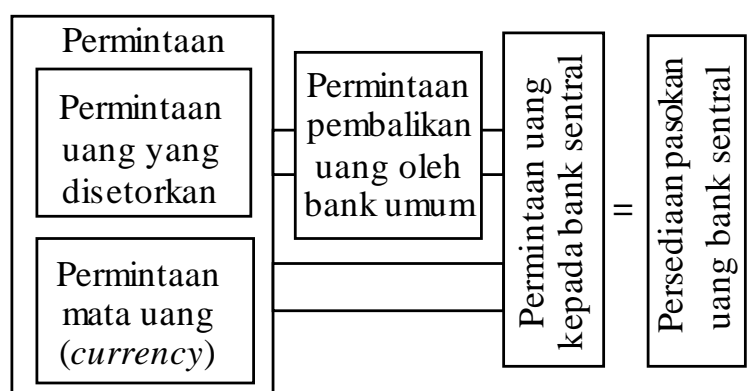

Gambar 4. Skema Permintaan dan Persediaan Pas okan Uang di Bank Sentral (Chinn \& University of Wiscons in, 2011)

Perancangan model prediksi disesuaikan berdasarkan Gambar 3 yaitu skema permintaan dan persediaan uang di bank sentral sebagai gambaran bagaimana sistem keuangan berlangsung antara masyarakat, bank umum, dan bank sentral. Sistem keuangan tersebut menunjukkan adanya saling keterkaitan antara inflow dan outflow uang kartal yang dilakukan oleh suatu bank umum dengan bank sentral. Sehingga dapat dibuat model inflow menggunakan data outflow dan model outflow menggunakan data inflow. 


\subsection{Rancangan Model Prediksi Inflow dan Outflow Uang Kartal di Provinsi Bali}

Berikut state space matriks dari rancangan model inflow dan outflow uang kartal di Provinsi Bali berdasarkan skema Gambar 3 (Chinn \& University of Wisconsin, 2011) dan data yang telah disiapkan.

$$
\begin{aligned}
& \text { output }=\psi(\text { input }) \\
& \begin{aligned}
Y_{\text {outflow }}= & F\left(p_{l} \text { (inflow }\right), \exists \sum(H R \\
& \left.\times b), d_{\text {bulan }}\right)
\end{aligned} \\
& \begin{array}{l}
Y_{\text {inflow }}=F\left(p_{l} \text { (outflow }\right), \exists \sum(H R \times \\
\left.b), d_{\text {bulan }}\right)
\end{array}
\end{aligned}
$$

Kemudian model dianalisis dalam sistem ANFIS untuk menghasilkan model yang akurat berdasarkan nilai mean average percentage error (MAPE) dan normalized root mean square error (NRMSE).

\subsection{Analisis Model Inflow dan Outflow Uang Kartal di Provinsi Bali}

Berikut analisis model prediksi inflow dan outflow uang kartal di Provinsi Bali. Model disimulasikan secara walk forward validation dari prediksi data 24 bulan terakhir.

\section{i. Penentuan partisi}

Penentuan partisi $(p)$ SWTS untuk melihat panjang segmen $(l)$ data input yang akurat sebagai indikator utama dalam suatu output. output $=\psi($ input $)$

$Y_{\text {inflow }}=F\left(p_{l}(\right.$ outflow $\left.)\right)$

$Y_{\text {outflow }}=F\left(p_{l}(\right.$ inflow $\left.)\right)$

Tabel 2. Error Simulasi Berdasarkan Panjang Segmen Tiap Partisi

\begin{tabular}{|l|r|r|r|r|}
\hline \multirow{2}{*}{$(\boldsymbol{l})$} & \multicolumn{2}{|c|}{ Prediksi Outflow } & \multicolumn{2}{c|}{ Prediksi Inflow } \\
\cline { 2 - 5 } & MAPE & NRMSE & MAPE & NRMSE \\
\hline 1 & $38,25 \%$ & $23,42 \%$ & $29,95 \%$ & $20.93 \%$ \\
\hline 2 & $33,09 \%$ & $21,90 \%$ & $25,23 \%$ & $18,54 \%$ \\
\hline 3 & $37,42 \%$ & $22,86 \%$ & $28,71 \%$ & $18,39 \%$ \\
\hline 4 & $69,58 \%$ & $83,93 \%$ & $31,09 \%$ & $20,40 \%$ \\
\hline
\end{tabular}

Tabel 2 menunjukkan error simulasi inflow dan outflow uang kartal di Provinsi Bali dengan menyesuaikan panjang segmen $(l)$ tiap partisi. Hasil menunjukkan terpilih $l$ adalah dua untuk menghasilkan error yang minimum. Dalam langkah ini ditemukan banyaknya input segmen 3 dan 4 membuat jaringan tidak memprediksi dengan baik karena ditemukan output negatif dan terlampau tinggi dalam simulasinya.

\section{ii. Penambahan Variabel Hari Raya dan Pembobotan Diskrit}

Penambahan variabel hari raya dalam model terpilih (i), bertujuan untuk meningkatkan performa prediksi inflow dan outflow uang kartal di Provinsi Bali. Tabel 3 menunjukkan hasil simulasi model dengan hari raya tunggal untuk variabel $g, f, n$, dan $s$.

Tabel 3. Error Simulasi Model Terpilih (i) dengan Tambahan Variabel Hari Raya

\begin{tabular}{|c|r|r|r|r|}
\hline \multirow{2}{*}{ HR } & \multicolumn{2}{|c|}{ Prediksi Outflow } & \multicolumn{2}{c|}{ Prediksi Inflow } \\
\cline { 2 - 5 } & MAPE & NRMSE & MAPE & NRMSE \\
\hline$g$ & $29,87 \%$ & $21,01 \%$ & $27,57 \%$ & $19,38 \%$ \\
\hline$f$ & $27,40 \%$ & $15,75 \%$ & $32,65 \%$ & $23,09 \%$ \\
\hline$n$ & $32,52 \%$ & $22,08 \%$ & $28,64 \%$ & $19,93 \%$ \\
\hline$s$ & $41,90 \%$ & $33,86 \%$ & $30,71 \%$ & $23,04 \%$ \\
\hline
\end{tabular}

Tabel 3 menunjukkan penggunaan salah satu hari raya tidak seluruhnya meningkatkan akurasi model.

output $=\psi($ input $)$

$Y_{\text {inflow }}=F\left(p_{2}\right.$ (outflow), $\left.\exists \sum(H R \times b)\right)$

$Y_{\text {outflow }}=F\left(p_{2}\right.$ (inflow), $\left.\exists \sum(H R \times b)\right)$

Pembobotan diskrit digunakan sebagai alternatif untuk penggabungan semua identifikasi hari raya ke dalam model. Sehingga variabel yang terbentuk tidak terlalu mempengaruhi kompleksitas jaringan ANFIS dan mampu menggambarkan semua kejadian hari raya yang diidentifikasi.
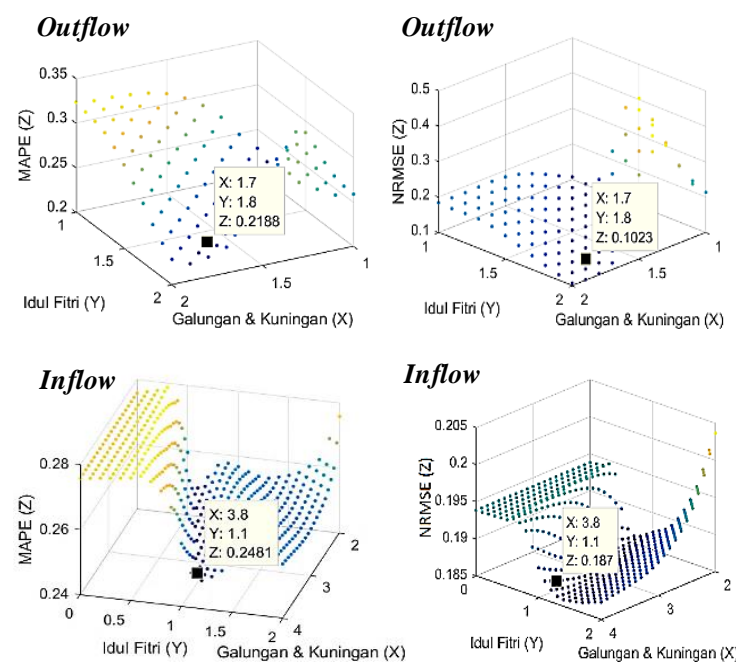

Gambar 5. Pengujian Error Simulasi dengan Pembobotan Diskrit Hari Raya Galungan, Kuningan, dan Idul Fitri dalam Model 
Gambar 5 menunjukkan grafik pengujian error simulasi dengan pembobotan diskrit berjarak 0,1 untuk hari raya Galungan, Kuningan, dan Idul Fitri yang mampu meningkatkan keakuratan model. Pada gambar dipilih titik diskrit yang menghasilkan MAPE terkecil, karena hampir sebagian besar nilai NRMSE lebih kecil dari MAPE.
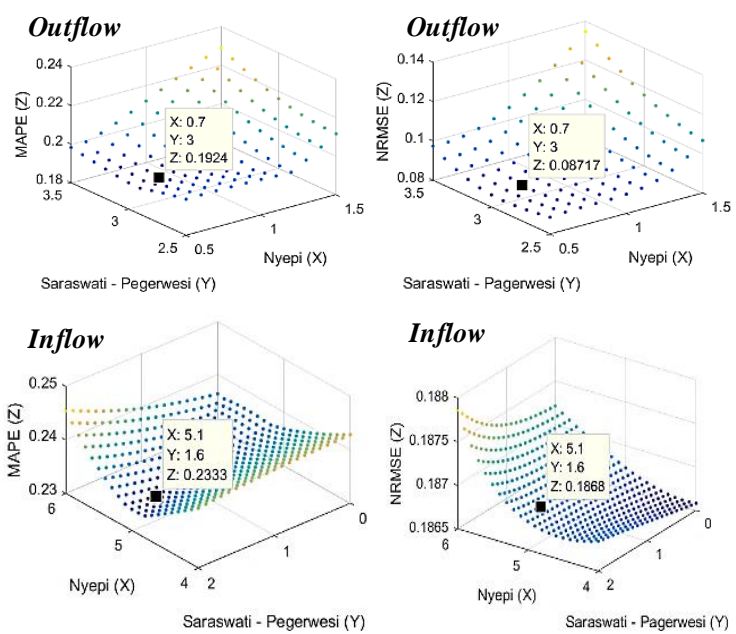

Gambar 6. Pengujian Error Simulasi dengan Penambahan dan Pembobotan Diskrit Hari Raya Nyepi, Saras wati, dan Pagerwesi

Gambar 6 menunjukkan grafik pengujian error simulasi dengan pembobotan diskrit berjarak 0,1 untuk Nyepi, Saraswati, dan Pagerwesi dari model terpilih di Gambar 5. Pada gambar dipilih titik diskrit yang menghasilkan MAPE terkecil, karena hampir sebagian besar nilai NRMSE lebih kecil dari MAPE.

Sehingga diperoleh model berikut dengan performa prediksi outflow yaitu MAPE 19,24\% dan NRMSE $8,71 \%$ sedangkan inflow yaitu MAPE 23,33\% dan NRMSE 18,68\%.

$Y_{\text {inflow }}=F\left(p_{2}\right.$ (outflow $),\left(H_{g k} \times 1,7+\right.$

$\left.\left.H_{\text {if }} \times 1,8+H_{n} \times 0,7+H_{s p} \times 3\right)\right)$

$Y_{\text {outflow }}=F\left(p_{2}\right.$ (inflow $),\left(H_{g} \times 3,8+H_{f} \times\right.$

$\left.\left.1,1+H_{n} \times 5,1+H_{s} \times 1,6\right)\right)$

\section{iii. Penambahan Dummy Bulan}

Variabel dummy sebelum diproses oleh ANFIS akan diproses terlebih dahulu dengan algoritme mean encoding. Nilai tiap data nominal 1-12 akan berubah menjadi rataan output per nama bulan dalam data training untuk meminimalkan kompleksitas model.
Tabel 4. Perbandingan Error Simulasi Model Berdasarkan Variabel yang Digunakan

\begin{tabular}{|c|c|c|c|c|}
\hline M & \multicolumn{2}{|c|}{ Variabel Input } & MAPE & NRMSE \\
\hline \multirow{4}{*}{ 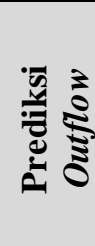 } & \multirow{4}{*}{ 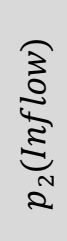 } & - & $33,09 \%$ & $21,90 \%$ \\
\hline & & Bulan & $33,74 \%$ & $20,59 \%$ \\
\hline & & $\begin{array}{l}\text { Hari raya, } \\
\text { bulan }\end{array}$ & $26,73 \%$ & $11,11 \%$ \\
\hline & & Hari raya & $19,24 \%$ & $8,71 \%$ \\
\hline \multirow{4}{*}{ 竎 } & \multirow{4}{*}{ 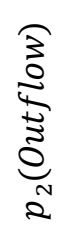 } & - & $25,23 \%$ & $18,54 \%$ \\
\hline & & Bulan & $24,25 \%$ & $18,38 \%$ \\
\hline & & $\begin{array}{l}\text { Hari raya, } \\
\text { bulan }\end{array}$ & $26,92 \%$ & $18,03 \%$ \\
\hline & & Hari raya & $23,33 \%$ & $18,68 \%$ \\
\hline
\end{tabular}

Tabel 4 menunjukkan simulasi model yang menggunakan variabel dummy bulan dalam studi ini, tidak lebih akurat dibandingkan model yang hanya menggunakan variabel hari raya dengan pembobotannya.

\section{iv. Pemilihan Model dan Grafik Simulasinya}

Model inflow dan outflow di Provinsi Bali terpilih dalam penelitian ini yaitu model yang menggunakan variabel hari raya dengan pembobotannya. Pemilihan berdasarkan simulasi prediksi 24 bulan terakhir secara walk forward validation dan nilai error terkecil. Berikut hasil simulasi model terpilih yang ditunjukkan Gambar 7.
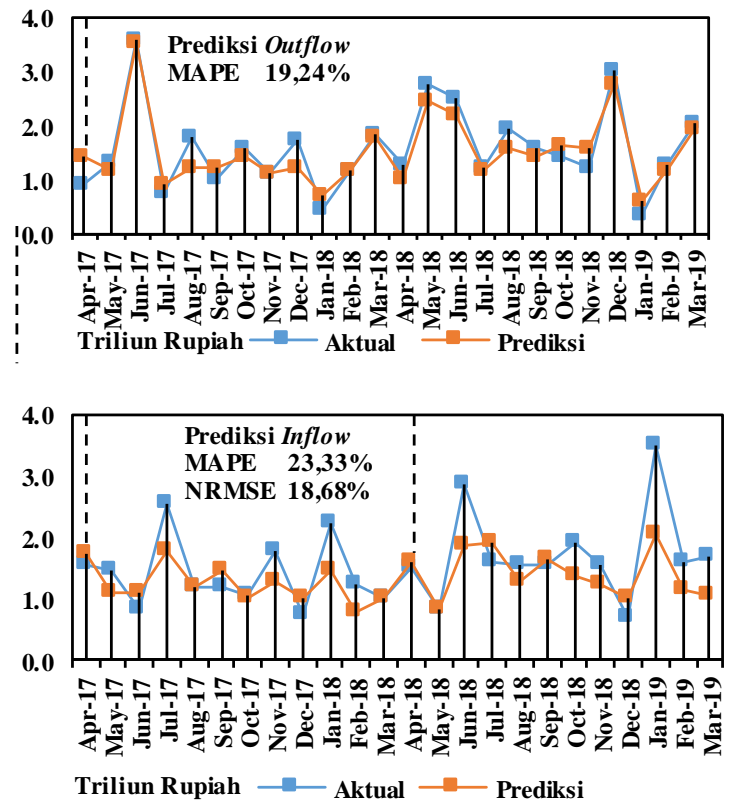

Gambar 7. Simulasi Prediksi Inflow dan Outflow Uang Kartal di Provinsi Bali 


\section{KESI MPULAN DAN SARAN}

\subsection{Kesimpulan}

Model neuro-fuzzy dalam studi ini dapat digunakan untuk memprediksi inflow dan outflow uang kartal di Provinsi Bali adalah model yang menggunakan variabel hari raya dengan pembobotannya. Berdasarkan simulasi 24 bulan terakhir, performa prediksi inflow diperoleh MAPE 23,33\% (patut dipertimbangkan) dan NRMSE $18,68 \%$ (akurat). Sedangkan performa prediksi outflow diperoleh MAPE 19,24\% (akurat) dan NRMSE $8,71 \%$ (sangat akurat). Jadi, metode neurofuzzy dapat digunakan sebagai model prediksi inflow dan outflow uang kartal di Provinsi Bali secara bulanan.

\subsection{Saran}

Adapun beberapa saran dari hasil penelitian ini yang dapat diteliti lebih lanjut.

1. Konsep sliding window time series analysis mengizinkan segmentasi untuk partisi output, sehingga membuka celah penelitian prediksi inflow dan outflow uang kartal untuk beberapa bulan ke depan.

2. Penelitian ini hanya menggunakan 4 variabel hari raya keagamaan, disarankan menambah hari raya yang mungkin dapat meminimalkan error.

3. Penelitian ini menggunakan beberapa hari raya sekaligus, disarankan untuk melakukan penelitian lebih lanjut yang fokus ke hari raya Galungan dan Kuningan sebagai hari raya besar penduduk mayoritas untuk menemukan hal baru di dalamnya.

4. Hari raya Idul Fitri merupakan hari raya penduduk minoritas di Provinsi Bali dan memberikan efek paling signifikan terhadap prediksi outflow uang kartal. Hal ini merupakan hal yang menarik untuk diteliti lebih lanjut di lingkup perbankan sekaligus masyarakat, karena arus uang kartal di masyarakat dilakukan oleh bank sebagai pihak yang secara langsung berkomunikasi dengan bank sentral.

5. Arsitektur standar ANFIS grid partition dapat menghasilkan output negatif atau terlalu tinggi saat dimensi variabel input lebih dari 3 walaupun sudah dinormalisasi. Hal ini dapat diteliti lebih lanjut untuk menemukan solusi arsitektur ANFIS yang dapat menerima input variabel yang lebih banyak untuk memprediksi inflow dan outflow uang kartal di Provinsi Bali.

6. Penelitian ini tidak menemukan model yang akurat untuk memprediksi inflow dan outflow uang kartal di Provinsi Bali dengan menggunakan variabel dummy bulan. Disarankan melakukan penelitian lebih lanjut terkait hal ini.

\section{DAFTAR PUSTAKA}

BalaBali, 2012. BalaBali Kalender. [Online] Available at: http://www.balabali.com/id/balabalikalender-id [Diakses 1310 2019].

Bank Indonesia, 2013. Sistem Pembayaran Bank Sentral Republik Indonesia. [Online] Available at: https://www.bi.go.id/id/sistempembayaran/Contents/Default.aspx [Diakses 1006 2019].

Chinn, M. \& University of Wisconsin, 2011. Economics 302 Section 001: Intermediate Macroeconomic Theory. [Online] Available at: https://ww w.ssc. wisc.edu/ mchinn/web302 s11.html [Diakses 0207 2020].

Lewis, C., 1982. Industrial and business forecasting methods. London: Butterworths.

Mozaffari, L., Mozaffari , A. \& L. Azad, N., 2014. Vehicle speed prediction via a sliding-window time series analysis and an evolutionary least learning machine: A case study on San Francisco urban roads. Engineering Science and Technology, an International Journal (ELSEVIER), pp. 113.

Navarro, R. I., Dalmases, O. L. \& Akhi-Elarab, F. N., 2013. Annexl: Introduction to Neural Networks and Adaptive NeuroFuzzy Inference Systems (ANFIS), Barcelona: Universitat Politècnica de Catalunya. 